\title{
Nitrogen response efficiency of a managed and phytodiverse temperate grassland
}

\author{
Andreas Keuter • Ina Hoeft • Edzo Veldkamp • \\ Marife D. Corre
}

Received: 29 December 2011 / Accepted: 25 June 2012 / Published online: 13 July 2012

(C) The Author(s) 2012. This article is published with open access at Springerlink.com

\begin{abstract}
Aims Our goal was to assess how management and sward functional diversity affect nitrogen response efficiency (NRE), the ratio of plant biomass production to supply of available nitrogen $(\mathrm{N})$ in temperate grassland.

Methods A three-factorial design was employed: three sward compositions, two mowing frequencies, and two fertilization treatments.

Results NRE was largely influenced by fertilization followed by mowing frequency and sward composition. NRE was larger in unfertilized than fertilized plots, in plots cut thrice than plots cut once per year, and in control swards than in monocot- or dicotenhanced swards. Fertilization decreased NRE through decreases in both $\mathrm{N}$ uptake efficiency (plant $\mathrm{N}$ uptake per supply of available $\mathrm{N}$ ) and $\mathrm{N}$ use efficiency (NUE, biomass produced per plant $\mathrm{N}$ uptake) whereas mowing frequency and sward composition affected NRE through $\mathrm{N}$ uptake efficiency rather than NUE. The largest NRE in the control sward with $70 \%$
\end{abstract}

Responsible Editor: Harry Olde Venterink.

Andreas Keuter and Ina Hoeft contributed equally to this work.

A. Keuter $(\bowtie) \cdot$ I. Hoeft $(\square) \cdot$ E. Veldkamp $\cdot$ M. D. Corre Soil Science of Tropical and Subtropical Ecosystems, Büsgen Institute, Georg-August-Universität Göttingen, Büsgenweg 2,

37077 Göttingen, Germany

e-mail: akeuter@gwdg.de

e-mail: ihoeft@gwdg.de monocots and $30 \%$ dicots attests that these proportions of functional groups were best adapted in this grassland ecosystem.

Conclusions Optimum NRE may not be a target of most farmers, but it is an appropriate tool to evaluate the consequences of grassland management practices, which farmers may employ to maximize profit, on environmental quality.

Keywords $\mathrm{N}$ uptake efficiency $\cdot \mathrm{N}$ use efficiency $\cdot \mathrm{Net}$ $\mathrm{N}$ mineralization rates $\cdot$ Functional diversity

\section{Abbreviations \\ NRE Nitrogen response efficiency \\ NUE Nitrogen use efficiency}

\section{Introduction}

Nutrient response efficiency, the amount of biomass produced per unit of plant-available nutrients (Pastor and Bridgham 1999), is a measure of ecosystem functioning that integrates productivity and the retention of nutrients (Hiremath and Ewel 2001). In terrestrial ecosystems where nitrogen $(\mathrm{N})$ is limiting net primary productivity (Vitousek and Howarth 1991), the efficient use of available $\mathrm{N}$ may give communities a competitive advantage over communities that are less efficient in using $\mathrm{N}$ (Bridgham et al. 1995). There is no common agreement about the 
definitions of nitrogen response efficiency (NRE) and nitrogen use efficiency (NUE) in literature (Xu et al. 2012; Aerts 1990; Vitousek 1982). In our study, NRE is calculated as the product of $\mathrm{N}$ uptake efficiency (defined as plant $\mathrm{N}$ concentration x plant biomass $\div$ soil available $\mathrm{N}$ ) and NUE (defined as plant biomass $\div$ plant $\mathrm{N}$ concentration $\mathrm{x}$ plant biomass), two indices that are commonly used to evaluate the role of $\mathrm{N}$ in ecosystem productivity (Pastor and Bridgham 1999). However, both indices give an incomplete picture of how $\mathrm{N}$ availability affects biomass production. A large NUE does not necessarily reflect a large productivity because NUE can increase or decrease if the plant $\mathrm{N}$ concentration changes even if plant biomass stays the same. NUE is also often not well correlated with soil $\mathrm{N}$ availability (Iversen et al. 2010). Similarly, N uptake efficiency does not directly indicate productivity as it is influenced by changes in plant $\mathrm{N}$ concentration. In contrast, NRE is an index that reflects the ability of plants to acquire $\mathrm{N}$ from the soil and to use it for biomass production once it is taken up (Bridgham et al. 1995), and thus it is a better index if biomass production is the main goal (as is the case in most temperate grasslands). Since a large NRE indicates a large biomass production per unit of soil available $\mathrm{N}$ and thus a large $\mathrm{N}$ retention in plants, it is inversely correlated with $\mathrm{N}$ lost, e.g. through nitrate $\left(\mathrm{NO}_{3}{ }^{-}\right)$leaching and gaseous $\mathrm{N}$ emissions. A large NRE may thus contribute to the reduction of reactive $\mathrm{N}$ in the soil, which affects water and air pollution as well as the emission of greenhouse gases (Dobermann 2005).

Pastor and Bridgham (1999) developed a general model of NRE showing maximum efficiency at intermediate levels of $\mathrm{N}$ availability. In their model, productivity $\left(\mathrm{P}_{\mathrm{N}}\right.$ supply $)$ at a given level of available $\mathrm{N}$ (i.e. $\mathrm{N}$ supply in the environment) is defined as:

$\mathrm{P}_{\mathrm{N} \text { supply }}=\mathrm{N}$ supply $*(\mathrm{P} \div \mathrm{N}$ supply $)+0$

In this model, NRE is the slope of a line from the origin to a given point of the function that describes the relationship between productivity and $\mathrm{N}$ supply (Pastor and Bridgham 1999). This implies that NRE changes with $\mathrm{N}$ supply and depends on the shape of the function in Eq. 1. If the relationship between productivity and $\mathrm{N}$ supply is linear, NRE is constant across a gradient of $\mathrm{N}$ supply. However, a linear relationship over a wide range of $\mathrm{N}$ supply is unlikely given the observation that no further increase in productivity occurs at high levels of $\mathrm{N}$ availability (Pastor and Bridgham 1999). Studies that investigated the relationships between NRE and soil $\mathrm{N}$ availability found increases in NRE as soil $\mathrm{N}$ availability declined in an experimental plantation of tropical trees (Hiremath and Ewel 2001; Yuan et al. 2006). Bridgham et al. (1995) gave a mathematical proof that nutrient response efficiency has to be unimodal across broad ranges of nutrient supply. However, the unimodal efficiency has not been observed for $\mathrm{N}$ so far and is debatable (Yuan et al. 2006). A monotonic increase of NRE with decreasing soil $\mathrm{N}$ availability was observed by Yuan et al. (2006) for Mongolian grassland.

NRE can be influenced by management practices and plant diversity through their effects on $\mathrm{N}$ availability, uptake efficiency and NUE. Management practices commonly employed in grasslands are fertilization and mowing. Fertilization directly influences $\mathrm{N}$ availability. Furthermore, mowing removes available $\mathrm{N}$ from the ecosystem through the mown biomass. In systems with large nutrient availability, mowing may mitigate the negative effects of nutrient enrichment on plant diversity by removing excess nutrients (Ellenberg and Leuschner 2010; Pykälä 2000). Mowing can also lead to a denser root system in the top soil by increasing the root-to-shoot-ratio and thus causing a more effective plant $\mathrm{N}$ uptake (Kammann et al. 1998; Mooney and Winner 1991). In contrast, an increase in allocation of resources to the shoots (Guitian and Bardgett 2000) as well as a decrease in root biomass following defoliation have been reported by other studies (Dawson et al. 2000; Holland and Detling 1990). Mikola et al. (2009) also reported that even for grazed grasslands defoliation is the most important mechanism explaining grazing effects on plant attributes while excreta return play only a minor role. To date, there are no published studies on how $\mathrm{N}$ fertilization, mowing frequency and their interactions affects NRE of temperate grasslands, and thus the present study is the first to report such pattern.

Apart from direct effects, management practices may also affect NRE through a change in species composition of the sward. In the past six decades, European grasslands have undergone many changes in management (e.g. increased fertilizer input and mowing frequency, or abandonment from agricultural use) that had profound consequences for biodiversity (Isselstein et al. 2005). The impact of plant 
diversity on nutrient uptake, productivity and NRE has been subject of several studies. Hiremath and Ewel (2001) reported an increase in $\mathrm{N}$ uptake efficiency with increase in life-form diversity for a tropical tree plantation. Several studies showed that more diverse grasslands were more productive (e.g. Hector et al. 1999; Tilman et al. 1996; Weigelt et al. 2009) with an increased nutrient retention from more diverse grassland ecosystems (Tilman et al. 1996). Furthermore, van Ruijven and Berendse (2005) observed an increase in productivity and NUE with increasing species richness. These studies, however, were conducted in experimentallyestablished plots that were weeded intensively, or in microcosms, making them difficult to compare with results from permanent grasslands where no clear effect of biodiversity on productivity has yet been demonstrated (Wrage et al. 2011). This may be due to the larger species richness in permanent grassland compared to many studies where diversity effects were largest at species richness levels smaller than five species (Wrage et al. 2011). Although Flombaum and Sala (2008) reported a larger effect of plant biodiversity on productivity in a natural grassland ecosystem compared to artificial ecosystems, their study only included a biodiversity gradient of one to six species, which is still considerably lower than managed, temperate grasslands with 10 to 60 plant species (Wrage et al. 2011). So far no studies on the impact of management practices, sward composition and their interactions on NRE in agriculturally-managed, permanent grassland have been published. As the efficiency with which grasslands use available $\mathrm{N}$ for biomass production is the key link between management and biogeochemical $\mathrm{N}$ cycling, our goal was to evaluate how NRE changes as a function of different management practices and sward compositions in an agriculturallymanaged, permanent grassland site. We measured NRE of a grassland site that was managed according to local practices in the Solling Mountains (Lower Saxony, Germany). Here, we only considered the harvestable, aboveground biomass because our study focuses on agricultural management practices. Plant functional group diversity was manipulated by herbicide treatments, resulting in dicot-enhanced swards with nearly equal proportions of dicots and monocots, control swards with $\sim 70 \%$ monocots and $\sim 30 \%$ dicots, and monocot-enhanced swards with $\sim 90 \%$ monocots and $\sim 10 \%$ dicots. Species richness was significantly smaller in the monocot-enhanced swards compared to the control swards (Petersen et al. 2011). $\mathrm{N}$ supply (used as the measure of $\mathrm{N}$ availability in the environment) was defined as the sum of soil net $\mathrm{N}$ mineralization rates during the growing season, $\mathrm{N}$ deposition from bulk precipitation, and fertilizer addition rates. We tested the following hypotheses: 1) unfertilized plots have larger NRE than fertilized plots, 2) plots with high mowing frequency have larger NRE than plots with low mowing frequency, and 3) NRE increases with increasing number of species (i.e. monocot-enhanced swards (12-13 species) < dicot-enhanced (17 species) and control swards (16-18 species)).

\section{Materials and methods}

Study site

This interdisciplinary research project, grassland management experiment or GRASSMAN, was conducted at the experimental farm of the University of Goettingen on a moderately species-rich grassland in the Solling Mountains in Lower Saxony, Germany $\left(51^{\circ} 44^{\prime} 53^{\prime \prime} \mathrm{N}, 9^{\circ} 32^{\prime} 42^{\prime \prime} \mathrm{E}, 490 \mathrm{~m}\right.$ above sea level). This permanent grassland site has traditionally been used as a pasture for hay making or for grazing (Geological Map of Prussia 1910 (based on the topographic inventory of 1896); topographic maps of Sievershausen and Neuhaus/Solling 1924, 1956 and 1974; Braunschweigische Landesaufnahme 18th century). In the last five decades, the study site was managed with moderate fertilization $(80 \mathrm{~kg} \mathrm{~N}$ $\mathrm{ha}^{-1} \mathrm{yr}^{-1}$ ), liming, overseeding with high value forage species and cattle grazing (farm records of Relliehausen since 1966). Fertilization stopped two years before our experiment started. Vegetation consists of a montane, semi-moist Lolio-Cynosuretum. Mean annual precipitation is $1028 \mathrm{~mm}$ and mean annual temperature is $6.9^{\circ} \mathrm{C}$ (Deutscher Wetterdienst, 19611990, station Holzminden-Silberborn, $440 \mathrm{~m}$ above sea level). During the study period, mean annual temperature and annual precipitation were $8.4{ }^{\circ} \mathrm{C}$ and $1001 \mathrm{~mm}$ in 2009 and $8.0{ }^{\circ} \mathrm{C}$ and $1110 \mathrm{~mm}$ in 2010. The dominating soil type is a Haplic Cambisol, developed on sediments of loess on the Middle Buntsandstein formation with a loamy silt texture. 
Experimental set up

The study had a three-factorial design: three sward compositions, two mowing frequencies and two fertilization treatments. In June 2008, we established three sward compositions by applying a herbicide mixture against dicotyledons (Starane ${ }^{\circledR}$ (active ingredients: Fluoroxypyr and Triclopyr) and Duplosan KV (active ingredients: Mecoprop- $\left.\mathrm{P}^{\circledR}\right)$ ) resulting in a sward with reduced proportions of herbs and legumes, a herbicide mixture against monocotyledons (Select $240 \mathrm{EC}^{\circledR}$ by Stähler (active ingredients: Clethodim)) resulting in a sward with reduced proportions of grasses, and an untreated control sward. Hereafter, we refer to these sward compositions as monocot-enhanced (12-13 species; 91-93\% grasses, $7-9 \%$ herbs and $0 \%$ legumes) and dicot-enhanced (17 species; 40-47\% grasses, $49-53 \%$ herbs and 4-9\% legumes) relative to the control sward (16-18 species; 68-76 \% grasses, $21-31 \%$ herbs and $1-4 \%$ legumes) (Petersen et al. 2011). In 2008, all experimental plots were mown, and fertilized plots received $50 \mathrm{~kg} \mathrm{Nha}^{-1}$. The experiment started in spring 2009 with two mowing frequencies (once per year in July and thrice per year in May, July and September) as well as two fertilization treatments $\left(180-30-100 \mathrm{~kg}\right.$ NPK ha ${ }^{-1} \mathrm{yr}^{-1}$ and no fertilization). The $\mathrm{N}$ fertilizer (calcium ammonium nitrate N27) was split into two equal applications per year (April and May 2009 and April and June 2010) while the combined $\mathrm{P}$ and $\mathrm{K}$ fertilizer was applied once a year (June 2009 and 2010). The experimental treatments were set up with 6 replicates in a full factorial design ( 72 plots; $15 \mathrm{~m} \times 15 \mathrm{~m}$ each) arranged in a Latin rectangle.

\section{Soil characteristics}

Soil characteristics (Table 1) were determined in spring 2008 (chemical and texture analyses) and summer 2009 (bulk density). At nine sampling points per plot, mineral soils (0.01-0.1 $\mathrm{m}$ depth) were sampled, pooled, oven-dried $\left(40{ }^{\circ} \mathrm{C}\right)$ for a week and sieved ( $2 \mathrm{~mm}$ ). Particle size distribution was determined by wet sieving $(>20<630 \mu \mathrm{m})$ and pipette methods $(\leq 20 \mu \mathrm{m})$ after pre-treatment with $30 \% \mathrm{H}_{2} \mathrm{O}_{2}$ and $4 \%$ Na-dithionite-citrate solution to remove organic matter and iron oxides (Schlichting et al. 1995). Soil bulk density was determined by soil core method (Blake and Hartge 1986). Cation exchange capacity (CEC) was determined using the method of $0.1 \mathrm{M}$ $\mathrm{BaCl}_{2}$ percolation (König and Fortmann 1996) and
Table 1 Soil characteristics in the Ah horizon (0.01-0.1 m) of a Haplic Cambisol of a grassland site in the Solling Mountains, Germany

\begin{tabular}{|c|c|c|c|}
\hline Physical and chemical ${ }^{\mathrm{a}}$ properties & Mean & $\mathrm{SE}$ & $n$ \\
\hline Sand $(\%)$ & 21.62 & 1.2 & 18 \\
\hline Silt (\%) & 66.53 & 1.3 & 18 \\
\hline Clay $(\%)$ & 11.85 & 0.8 & 18 \\
\hline Bulk density $\left(\mathrm{g} \mathrm{cm}^{-3}\right)$ & 0.79 & 0.01 & 72 \\
\hline $\begin{array}{l}\text { Cation exchange capacity } \\
\left(\mathrm{mmol}_{\mathrm{c}} \mathrm{kg}^{-1}\right)\end{array}$ & 169.00 & 5.2 & 72 \\
\hline Base saturation $(\%)$ & 37.18 & 1.4 & 72 \\
\hline $\mathrm{pH}\left(1: 2 \mathrm{H}_{2} \mathrm{O}\right)$ & 5.34 & 0.03 & 72 \\
\hline Carbon : Nitrogen ratio & 12.60 & 0.04 & 72 \\
\hline
\end{tabular}

${ }^{\text {a }}$ Soil chemical data were provided by the Department of Plant Ecology, University of Göttingen.

measuring cations in percolates using Inductively Coupled Plasma - Optical Emission Spectrometry (Optima 3000 XL, Perkin Elmer, Rodgau, Germany). Base saturation was determined as the percentage exchangeable base cations of the CEC. Soil $\mathrm{pH}$ was measured from soil:water suspension (ratio of 1:2). Total $\mathrm{C}$ and $\mathrm{N}$ concentrations were determined from ground soils using a CN elemental analyzer (Elementar Vario EL III, Hanau, Germany).

Biomass yield and plant $\mathrm{N}$ uptake

Data of aboveground biomass was reported by From et al. (2011) (see Appendix 1). The grassland was mown in mid-July for plots with one-cut $\mathrm{yr}^{-1}$ and in mid-May, mid-July and end of September of each year for plots with three-cuts $\mathrm{yr}^{-1}$. A Haldrup (C) forage combine harvester was used with a cutting height of $7 \mathrm{~cm}$. Dry mass of the biomass was determined by oven-drying at $60{ }^{\circ} \mathrm{C}$ to constant mass. Oven-dried plant samples from the second cut (mid-July) were ground and analyzed for total $\mathrm{N}$ concentration using a CNS elemental analyser (Elementar Vario El, Hanau, Germany). Plant $\mathrm{N}$ uptake $\left(\mathrm{kg} \mathrm{Nha}^{-1} \mathrm{yr}^{-1}\right)$ was calculated as: $\mathrm{N}$ concentration $\left(\mathrm{kg} \mathrm{N} \mathrm{kg}^{-1}\right) *$ biomass yield $\left(\mathrm{kg} \mathrm{ha}^{-1}\right.$ $\mathrm{yr}^{-1}$ ) (Hiremath and Ewel 2001).

Soil net $\mathrm{N}$ mineralization rates, $\mathrm{N}$ supply, and $\mathrm{N}$ response efficiency

Net $\mathrm{N}$ mineralization rates were measured five times (April, May, June, August and October) in 2009 and 
six times (April, May, June, July, August and September) in 2010 using the buried bag method. In each plot, two intact soil cores were taken from the $\mathrm{Ah}$ mineral soil $(0.01-0.10 \mathrm{~m})$. The soil from one core was transferred into a plastic bag, crumbled, mixed well, and extracted directly in the field by taking a subsample and adding this to a prepared bottle containing $150 \mathrm{ml} 0.5 \mathrm{ML}^{-1} \mathrm{~K}_{2} \mathrm{SO}_{4}$ (average dry soil mass to solution ratio was $1: 3)\left(T_{0}\right.$ cores). The other soil core was put in a plastic bag that was loosely tied to permit aeration but prevent rain from entering, inserted back into the hole to incubate in-situ for ten days, and extracted in a similar manner ( $T_{1}$ cores). The soil- $\mathrm{K}_{2} \mathrm{SO}_{4}$ bottles were brought to the laboratory within $6 \mathrm{~h}$, where extraction continued by shaking the bottles for one hour and filtering through $\mathrm{K}_{2} \mathrm{SO}_{4}$ prewashed filter papers ( $4 \mu \mathrm{m}$ nominal pore size). Extracts were immediately frozen until analysis. Ammonium $\left(\mathrm{NH}_{4}{ }^{+}\right)$and $\mathrm{NO}_{3}{ }^{-}$were measured using continuous flow injection colorimetry (Skalar, Cenco Instruments, Breda, The Netherlands), in which $\mathrm{NH}_{4}{ }^{+}$was determined using the Berthelot reaction method (Skalar Method 155-000) and $\mathrm{NO}_{3}{ }^{-}$was measured using the copper-cadmium reduction method (Skalar Method 461-000). Gravimetric moisture content was determined for each soil sample by ovendrying at $105{ }^{\circ} \mathrm{C}$ for $24 \mathrm{~h}$. Net $\mathrm{N}$ mineralization was calculated as the difference between $T_{1}$ - and $T_{0}$-mineral $\mathrm{N}\left(\mathrm{NH}_{4}^{+}+\mathrm{NO}_{3}^{-}\right)$. This assay of net production of mineral $\mathrm{N}$ in soil under in-situ conditions in the absence of plants provides an index of plant-available N (Hart et al. 1994).

$\mathrm{N}$ supply of each plot is defined as the sum of cumulative net $\mathrm{N}$ mineralization rates of the soil, $\mathrm{N}$ fertilization and $\mathrm{N}$ deposition rates. Cumulative net $\mathrm{N}$ mineralization rates during a growing season (i.e. April-September) were calculated by applying the trapezoid rule on time intervals between measured rates. For $\mathrm{N}$ deposition, we used a value of $12.6 \mathrm{~kg} \mathrm{~N} \mathrm{ha}^{-1} \mathrm{yr}^{-1}$ from bulk precipitation measured within the scope of the EU-level II monitoring program (Keuffel-Türk et al. in press). NRE was calculated for each plot as:

$$
\begin{aligned}
& \mathrm{NRE}\left(\mathrm{kg} \text { biomass } \mathrm{kg} \mathrm{N}^{-1}\right) \\
& =(\text { plant } \mathrm{N} \text { uptake } \div \mathrm{N} \text { supply }) \\
& \quad *(\text { biomass yield } \div \text { plant } \mathrm{N} \text { uptake })
\end{aligned}
$$

The ratio of plant $\mathrm{N}$ uptake to $\mathrm{N}$ supply is referred to as $\mathrm{N}$ uptake efficiency whereas the ratio of biomass yield to plant $\mathrm{N}$ uptake is the NUE (Hiremath and Ewel 2001; Pastor and Bridgham 1999).

\section{Statistical analyses}

Effects of treatments on time series data (net $\mathrm{N}$ mineralization rates) were tested using linear mixed effects models (LME) with treatments and their interactions as fixed effects and spatial replication and time as random effects. The LME model includes either 1) a variance function that allows different variances of the response variable for the fixed effects, 2) a first-order temporal autoregressive process that assumes the correlation between measurements decreases with increasing time difference, or 3) both if this improves the relative goodness of model fit based on the Akaike Information Criterion (Crawley 2007). Treatment effects on biomass yield, plant $\mathrm{N}$ uptake, N supply, NRE, NUE and uptake efficiency were assessed using three-way analysis of variance (ANOVA) with Tukey's HSD test. In all tests, if residual plots revealed non-normal distribution or nonhomogeneity of variance, we used either logarithmic or square root transformation (after adding a constant value if the dataset included negative values) and analyses were repeated. Effects were accepted as statistically significant if $P \leq 0.05$. All statistical analyses were conducted using the $\mathrm{R}$ version 2.11.1 (R Development Core Team 2009).

\section{Results}

Biomass yield and plant $\mathrm{N}$ uptake

In 2009, biomass yield ranged from $4,048 \mathrm{~kg} \mathrm{ha}^{-1} \mathrm{yr}^{-1}$ to $14,647 \mathrm{~kg} \mathrm{ha}^{-1} \mathrm{yr}^{-1}$ with an overall mean of 7,758 $( \pm 309$ SE) $\mathrm{kg} \mathrm{ha}^{-1} \mathrm{yr}^{-1}$. Fertilization as well as increasing mowing frequency increased biomass yield, and plots cut thrice per year responded stronger to fertilization than plots cut once per year (Appendix 1). In 2010, biomass yield decreased to values between 1,960 and $12,983 \mathrm{~kg} \mathrm{ha}^{-1} \mathrm{yr}^{-1}$ with a mean of $5,612 \mathrm{~kg} \mathrm{ha}^{-1} \mathrm{yr}^{-1}$. Compared to 2009, the interaction between mowing frequency and fertilization was even more pronounced (i.e. larger explained variance). Fertilization only resulted in larger yields in plots with three cuts per year whereas no fertilization effect could be detected in plots with one cut per year (Appendix 1). Apart from 
fertilization and mowing frequency, sward composition also influenced biomass yield in 2010 but it explained only a small fraction of the variation. Control swards had larger yields compared to monocot-enhanced swards and both did not differ from dicot-enhanced swards.

Plant $\mathrm{N}$ uptake in 2009 ranged from $51.37 \mathrm{~kg}$ $\mathrm{N} \mathrm{ha}{ }^{-1} \mathrm{yr}^{-1}$ to $340.84 \mathrm{~kg} \mathrm{~N} \mathrm{ha}^{-1} \mathrm{yr}^{-1}$ with a mean of $147.38( \pm 17.37 \mathrm{SE}) \mathrm{kg} \mathrm{ha}^{-1} \mathrm{yr}^{-1}$. Fertilization significantly enhanced plant $\mathrm{N}$ uptake and explained by far the largest part of its variance. This was followed by mowing frequency with larger plant $\mathrm{N}$ uptake in plots cut thrice than once a year (Table 2). However, an interaction between fertilization and mowing frequency showed that mowing frequency only affected plant $\mathrm{N}$ uptake on the fertilized plots. In 2010, plant $\mathrm{N}$ uptake ranged from $27.82 \mathrm{~kg} \mathrm{~N} \mathrm{ha}^{-1} \mathrm{yr}^{-1}$ to $273.39 \mathrm{~kg} \mathrm{~N} \mathrm{ha}^{-1} \mathrm{yr}^{-1}$ with a mean of $98.87( \pm 11.65$ SE) $\mathrm{kg} \mathrm{ha}^{-1} \mathrm{yr}^{-1}$. As before, fertilization, mowing frequency and their interaction showed significant effects with larger plant $\mathrm{N}$ uptake in fertilized than unfertilized plots, and in plots cut thrice than once per year. The effect of fertilization was less pronounced and that of mowing frequency was larger compared to 2009. Mowing frequency significantly affected plant $\mathrm{N}$ uptake on both fertilized and unfertilized plots, but fertilized plots were more strongly influenced than unfertilized plots (Table 2).

\section{Soil net $\mathrm{N}$ mineralization rates and $\mathrm{N}$ supply}

Net $\mathrm{N}$ mineralization rates showed a clear seasonal pattern with large rates in summer and small rates in spring and fall. In 2009, net $\mathrm{N}$ mineralization rates varied between -13 and $135 \mathrm{~kg} \mathrm{~N} \mathrm{ha}^{-1} \mathrm{mo}^{-1}$ with a mean of 29 ( $\pm 3 \mathrm{SE}$ ) $\mathrm{kg} \mathrm{N} \mathrm{ha}^{-1} \mathrm{mo}^{-1} \cdot \mathrm{NH}_{4}^{+}$was the dominant form of soil mineral $\mathrm{N}$ before incubation. On average, $\mathrm{NO}_{3}{ }^{-}$ constituted $33 \%$ of the soil mineral $\mathrm{N}$ but in $70 \%$ of all cases no $\mathrm{NO}_{3}{ }^{-}$was detectable. Net $\mathrm{N}$ mineralization rates were neither affected by sward composition nor by mowing frequency (Table 3). Only fertilizer application influenced net $\mathrm{N}$ mineralization rates. In 2010, net $\mathrm{N}$ mineralization rates ranged from -29 to $105 \mathrm{~kg} \mathrm{~N} \mathrm{ha}^{-1}$ $\mathrm{mo}^{-1}$ with a mean of $19( \pm 3 \mathrm{SE}) \mathrm{kg} \mathrm{N}^{-1} \mathrm{mo}^{-1}$. Unlike in 2009, not only fertilization but also mowing frequency

Table 2 Plant $\mathrm{N}$ uptake of a grassland under different management practices in the Solling Mountains, Germany

\begin{tabular}{|c|c|c|c|c|c|c|c|c|c|c|}
\hline \multirow[t]{2}{*}{ Main factors } & \multirow[t]{2}{*}{ Treatments } & \multirow[t]{2}{*}{$n$} & \multicolumn{4}{|l|}{2009} & \multicolumn{4}{|l|}{2010} \\
\hline & & & $\begin{array}{l}\text { Plant } \mathrm{N} \text { uptake } \\
\left(\mathrm{kg} \mathrm{N} \mathrm{ha}^{-1} \mathrm{yr}^{-1}\right)\end{array}$ & SE & $P$ & $\begin{array}{l}\text { Variance } \\
\text { explained } \\
(\%)\end{array}$ & $\begin{array}{l}\text { Plant N uptake } \\
\left(\mathrm{kg} \mathrm{N} \mathrm{ha}^{-1} \mathrm{yr}^{-1}\right)\end{array}$ & SE & $P$ & $\begin{array}{l}\text { Variance } \\
\text { explained } \\
(\%)\end{array}$ \\
\hline \multirow{4}{*}{$\begin{array}{l}\text { Sward } \\
\text { composition }\end{array}$} & & & & & 0.540 & 0.21 & & & 0.072 & 1.10 \\
\hline & control & 24 & $147.37 \mathrm{a}$ & 16.24 & & & $106.64 \mathrm{a}$ & 13.03 & & \\
\hline & $\begin{array}{l}\text { monocot- } \\
\text { enhanced }\end{array}$ & 24 & $143.20 \mathrm{a}$ & 15.69 & & & $94.23 \mathrm{a}$ & 12.26 & & \\
\hline & dicot-enhanced & 24 & $151.56 \mathrm{a}$ & 14.99 & & & $95.73 \mathrm{a}$ & 10.49 & & \\
\hline \multirow{3}{*}{$\begin{array}{l}\text { Mowing } \\
\text { frequency }\end{array}$} & & & & & $<0.001$ & 13.17 & & & $<0.001$ & 20.78 \\
\hline & once per year & 36 & $120.11 \mathrm{~b}$ & 8.35 & & & $71.27 \mathrm{~b}$ & 4.06 & & \\
\hline & thrice per year & 36 & $174.65 \mathrm{a}$ & 14.50 & & & $126.46 \mathrm{a}$ & 11.41 & & \\
\hline \multirow[t]{3}{*}{ Fertilization } & & & & & $<0.001$ & 66.88 & & & $<0.001$ & 56.66 \\
\hline & no & 36 & $85.93 \mathrm{~b}$ & 4.15 & & & $59.73 \mathrm{~b}$ & 2.66 & & \\
\hline & NPK & 36 & $208.83 \mathrm{a}$ & 9.47 & & & $138.00 \mathrm{a}$ & 9.78 & & \\
\hline $\begin{array}{l}\text { Fertilization } \mathrm{x} \\
\text { mowing } \\
\text { frequency }\end{array}$ & & & & & $<0.001$ & 5.40 & & & $<0.001$ & 7.93 \\
\hline no & once per year & 18 & $76.12 \mathrm{c}$ & 3.33 & & & $54.39 \mathrm{~d}$ & 3.26 & & \\
\hline NPK & once per year & 18 & $164.11 \mathrm{~b}$ & 6.91 & & & $88.15 \mathrm{~b}$ & 4.87 & & \\
\hline no & thrice per year & 18 & $95.75 \mathrm{c}$ & 6.90 & & & $65.06 \mathrm{c}$ & 3.88 & & \\
\hline NPK & thrice per year & 18 & $253.55 \mathrm{a}$ & 9.28 & & & $187.85 \mathrm{a}$ & 8.81 & & \\
\hline
\end{tabular}

Mean values with different letter indicate significant differences among treatments within main factors or within an interaction of main factors (three-way ANOVA with Tukey HSD at $P \leq 0.05$ ). Treatment interactions that were not significant are not reported. 
Table 3 Soil net N mineralization rates of a grassland under different management practices in the Solling Mountains, Germany

\begin{tabular}{|c|c|c|c|c|c|c|c|c|}
\hline \multirow[t]{2}{*}{ Main factors } & \multirow[t]{2}{*}{ Treatments } & \multirow[t]{2}{*}{$n$} & \multicolumn{3}{|l|}{2009} & \multicolumn{3}{|l|}{2010} \\
\hline & & & $\begin{array}{l}\text { Net } \mathrm{N} \text { mineralization } \\
\left(\mathrm{kg} \mathrm{N} \mathrm{ha}^{-1} \mathrm{mo}^{-1}\right)\end{array}$ & SE & $P$ & $\begin{array}{l}\text { Net } \mathrm{N} \text { mineralization } \\
\left(\mathrm{kg} \mathrm{N} \mathrm{ha}^{-1} \mathrm{mo}^{-1}\right)\end{array}$ & SE & $P$ \\
\hline \multirow[t]{4}{*}{ Sward composition } & & & & & 0.560 & & & 0.160 \\
\hline & control & 24 & $30.69 \mathrm{a}$ & 11.70 & & $16.75 \mathrm{a}$ & 7.87 & \\
\hline & dicot-enhanced & 24 & $25.56 \mathrm{a}$ & 8.42 & & $24.20 \mathrm{a}$ & 9.47 & \\
\hline & monocot-enhanced & 24 & $21.19 \mathrm{a}$ & 7.58 & & $18.05 \mathrm{a}$ & 5.88 & \\
\hline \multirow[t]{3}{*}{ Mowing frequency } & & & & & 0.400 & & & 0.018 \\
\hline & once per year & 36 & $24.77 \mathrm{a}$ & 7.69 & & $22.54 \mathrm{a}$ & 3.76 & \\
\hline & thrice per year & 36 & $26.83 \mathrm{a}$ & 7.69 & & $16.76 \mathrm{~b}$ & 2.79 & \\
\hline \multirow[t]{3}{*}{ Fertilization } & & & & & $<0.001$ & & & 0.009 \\
\hline & no & 36 & $13.50 \mathrm{~b}$ & 3.47 & & $15.48 \mathrm{~b}$ & 2.58 & \\
\hline & NPK & 36 & $38.12 \mathrm{a}$ & 9.89 & & $23.84 \mathrm{a}$ & 3.97 & \\
\hline
\end{tabular}

Mean values with different letter indicate significant differences among treatments within main factors or within an interaction of main factors (Linear mixed effects models at $P \leq 0.05$ ). Treatment interactions that were not significant are not reported.

influenced net $\mathrm{N}$ mineralization rates: plots cut once per year showed larger net $\mathrm{N}$ mineralization rates than plots cut three times per year.

$\mathrm{N}$ supply in 2009 ranged from 15 to $1,003 \mathrm{~kg} \mathrm{~N} \mathrm{ha}^{-1} \mathrm{yr}^{-1}$ with a mean of $278( \pm 25 \mathrm{SE})$ $\mathrm{kg} \mathrm{N} \mathrm{ha}{ }^{-1} \mathrm{yr}^{-1}$. In 2010, $\mathrm{N}$ supply ranged from 22 to $823 \mathrm{~kg} \mathrm{~N} \mathrm{ha}^{-1} \mathrm{yr}^{-1}$ with a mean of 217 ( $\pm 18 \mathrm{SE}$ ) $\mathrm{kg} \mathrm{N} \mathrm{ha}{ }^{-1} \mathrm{yr}^{-1}$. In both years, fertilization $(P=0.000)$ was the only factor influencing $\mathrm{N}$ supply.

$\mathrm{N}$ response efficiency, $\mathrm{N}$ uptake efficiency and $\mathrm{N}$ use efficiency

NRE in 2009 varied in a wide range from 10 to $488 \mathrm{~kg}$ biomass $\mathrm{kg} \mathrm{N}$ supply $^{-1}$ with a mean of 48 ( $\left.\pm 7 \mathrm{SE}\right) \mathrm{kg}$ biomass $\mathrm{kg} \mathrm{N}$ supply $^{-1}$. Fertilization was the main factor influencing NRE, with larger efficiency in unfertilized plots compared to fertilized plots (Table 4). Mowing frequency was the second important factor that explained the variance, with larger NRE in plots cut thrice than once per year. In 2010, NRE did not differ from 2009 with values ranging from $5 \mathrm{~kg}$ to $162 \mathrm{~kg}$ biomass $\mathrm{kg} \mathrm{N}$ supply $^{-1}$ and a mean of $42( \pm 4 \mathrm{SE}) \mathrm{kg}$ biomass $\mathrm{kg} \mathrm{N}$ supply ${ }^{-1}$. All three factors significantly affected NRE in 2010, with fertilization explaining the largest part of the variance followed by mowing frequency and sward composition. NRE was larger in unfertilized than in fertilized plots. The interaction between sward composition and mowing frequency indicated that regardless of mowing frequency, control plots showed an NRE comparable to the monocot- and dicotenhanced plots that were cut thrice a year and that these NRE were larger than those in monocot- and dicotenhanced plots cut once a year (Table 4). Within the covered range of $\mathrm{N}$ supply, NRE increased monotonically with decreasing N supply (Fig. 1a).

$\mathrm{N}$ uptake efficiency in 2009 was largely affected by fertilization with larger efficiencies in unfertilized plots compared to fertilized plots (Table 5). Mowing frequency explained a small part of the variance with larger efficiencies in plots cut thrice per year than plots cut only once per year. In 2010, mowing frequency explained a larger part of the variance than fertilization. In addition, sward composition marginally influenced $\mathrm{N}$ uptake efficiency with a larger efficiency in control swards than monocot- and dicot-enhanced swards (Table 5). The pattern between NRE and $\mathrm{N}$ uptake efficiency showed increasing NRE with increasing $\mathrm{N}$ uptake efficiency (Fig. 1b).

NUE was affected by all three factors in 2009 (Table 6). Fertilization was the most important factor influencing NUE. Unfertilized plots showed larger NUE than fertilized plots. Mowing was the second most important factor. Plots cut once per year showed larger NUE than plots cut thrice per year. This trend, however, was only significant for the unfertilized plots, based on fertilization and mowing interaction effect. Sward composition had the smallest influence with the largest NUE in monocot-enhanced swards, intermediate NUE in control swards and smallest NUE in dicot-enhanced swards. 
Table 4 N response efficiency (NRE) of a grassland under different management practices in the Solling Mountains, Germany

\begin{tabular}{|c|c|c|c|c|c|c|c|c|c|c|}
\hline \multirow[t]{2}{*}{ Main factors } & \multirow[t]{2}{*}{ Treatments } & \multirow[t]{2}{*}{$n$} & \multicolumn{4}{|l|}{2009} & \multicolumn{4}{|l|}{2010} \\
\hline & & & $\begin{array}{l}\mathrm{NRE} \\
(\mathrm{kg} \text { biomass } \\
\text { kg N supply }^{-1} \text { ) }\end{array}$ & SE & $P$ & $\begin{array}{l}\text { Variance } \\
\text { explained } \\
(\%)\end{array}$ & $\begin{array}{l}\text { NRE } \\
(\text { kg biomass } \\
\text { kg N supply }^{-1} \text { ) }\end{array}$ & $\mathrm{SE}$ & $P$ & $\begin{array}{l}\text { Variance } \\
\text { explained } \\
(\%)\end{array}$ \\
\hline \multirow[t]{4}{*}{ Sward composition } & & & & & 0.349 & 1.72 & & & 0.034 & 5.68 \\
\hline & control & 24 & $40.19 \mathrm{a}$ & 6.01 & & & $50.28 \mathrm{a}$ & 7.02 & & \\
\hline & $\begin{array}{l}\text { monocot- } \\
\text { enhanced }\end{array}$ & 24 & $59.99 \mathrm{a}$ & 18.82 & & & $42.62 \mathrm{ab}$ & 7.46 & & \\
\hline & dicot-enhanced & 24 & $45.30 \mathrm{a}$ & 6.10 & & & $32.94 \mathrm{~b}$ & 4.52 & & \\
\hline \multirow[t]{3}{*}{ Mowing frequency } & & & & & 0.047 & 3.29 & & & $<0.001$ & 12.40 \\
\hline & once per year & 36 & $38.67 \mathrm{~b}$ & 4.81 & & & $35.53 \mathrm{~b}$ & 5.68 & & \\
\hline & thrice per year & 36 & $58.31 \mathrm{a}$ & 13.30 & & & $48.37 \mathrm{a}$ & 5.03 & & \\
\hline \multirow[t]{3}{*}{ Fertilization } & & & & & $<0.001$ & 41.26 & & & $<0.001$ & 24.72 \\
\hline & no & 36 & $70.97 \mathrm{a}$ & 12.83 & & & $55.49 \mathrm{a}$ & 5.29 & & \\
\hline & NPK & 36 & $26.02 \mathrm{~b}$ & 2.18 & & & $28.41 \mathrm{~b}$ & 4.63 & & \\
\hline $\begin{array}{l}\text { Sward composition } \\
\text { x mowing } \\
\text { frequency }\end{array}$ & & & & & n.s. & n.s. & & & 0.036 & 5.54 \\
\hline control & once per year & 12 & & & & & $54.02 \mathrm{a}$ & 12.82 & & \\
\hline control & thrice per year & 12 & & & & & $46.54 \mathrm{a}$ & 6.77 & & \\
\hline monocot-enhanced & once per year & 12 & & & & & $29.84 \mathrm{~b}$ & 8.62 & & \\
\hline monocot-enhanced & thrice per year & 12 & & & & & $55.40 \mathrm{a}$ & 11.73 & & \\
\hline dicot-enhanced & once per year & 12 & & & & & $22.73 \mathrm{~b}$ & 4.48 & & \\
\hline dicot-enhanced & thrice per year & 12 & & & & & $43.16 \mathrm{a}$ & 7.04 & & \\
\hline
\end{tabular}

Mean values with different letter indicate significant differences among treatments within main factors or within an interaction of main factors (three-way ANOVA with Tukey HSD at $P \leq 0.05$ ). Treatment interactions that were not significant are not reported. n.s. $=$ not significant

In 2010, fertilization was the only factor influencing NUE (Table 6). The trend between NRE and NUE was more scattered (Fig. 1c) than the pattern between NRE and $\mathrm{N}$ uptake efficiency (Fig. 1b).

\section{Discussion}

Soil net $\mathrm{N}$ mineralization, plant $\mathrm{N}$ uptake and biomass yield

The substantial increase of net $\mathrm{N}$ mineralization following first fertilization in 2009 was probably caused by a priming effect. Priming effects are changes in mineralization processes caused by moderate addition of nutrients to the soil, e.g. the input of a limiting factor for microbial biomass (Kuzyakov et al. 2000). Our experimental site had been used for hay production and cattle grazing since the early 20th century.
Only during the last five decades, a minimal fertilizer addition of $80 \mathrm{~kg} \mathrm{~N}^{-1} \mathrm{yr}^{-1}$ was practiced. It is thus likely that the activity of microbial biomass was stimulated by the addition of $180 \mathrm{~kg} \mathrm{~N} \mathrm{ha}^{-1} \mathrm{yr}^{-1}$ at the beginning of our study. The reduction in net $\mathrm{N}$ mineralization rates in fertilized plots in the second year compared to the first year is also indicative of a priming effect, which has been suggested to be short term (Kuzyakov et al. 2000). While the addition of $\mathrm{N}$ fertilizer initially stimulates mineralization after a long period of $\mathrm{N}$ limitation, regular $\mathrm{N}$ additions may not increase $\mathrm{N}$ cycling continuously (Hassink 1994). The decreased net $\mathrm{N}$ mineralization rates with increased mowing frequency in the second year could be due to reduced input of organic matter into the soil as a consequence of the removal of biomass (Holt 1997; Mikola et al. 2001; Northup et al. 1999; Sankaran and Augustine 2004). Alternatively, it is possible that the reduced net $\mathrm{N}$ mineralization rates on the plots cut 


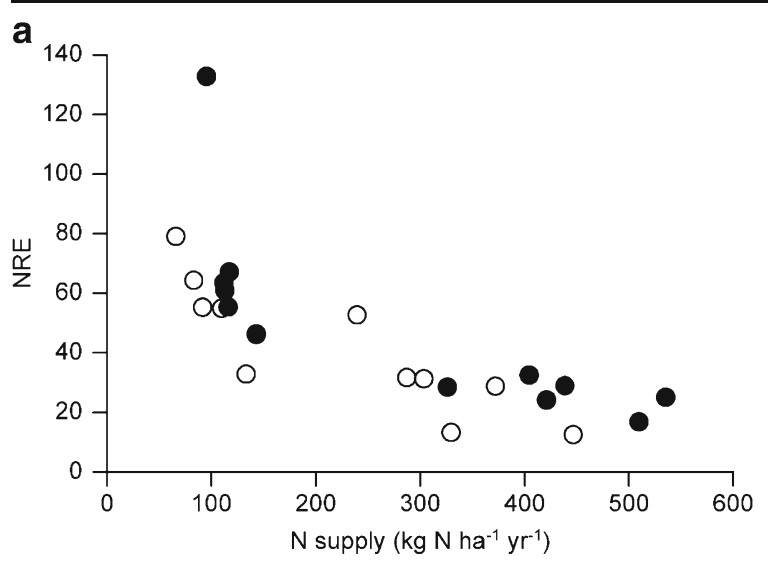

b
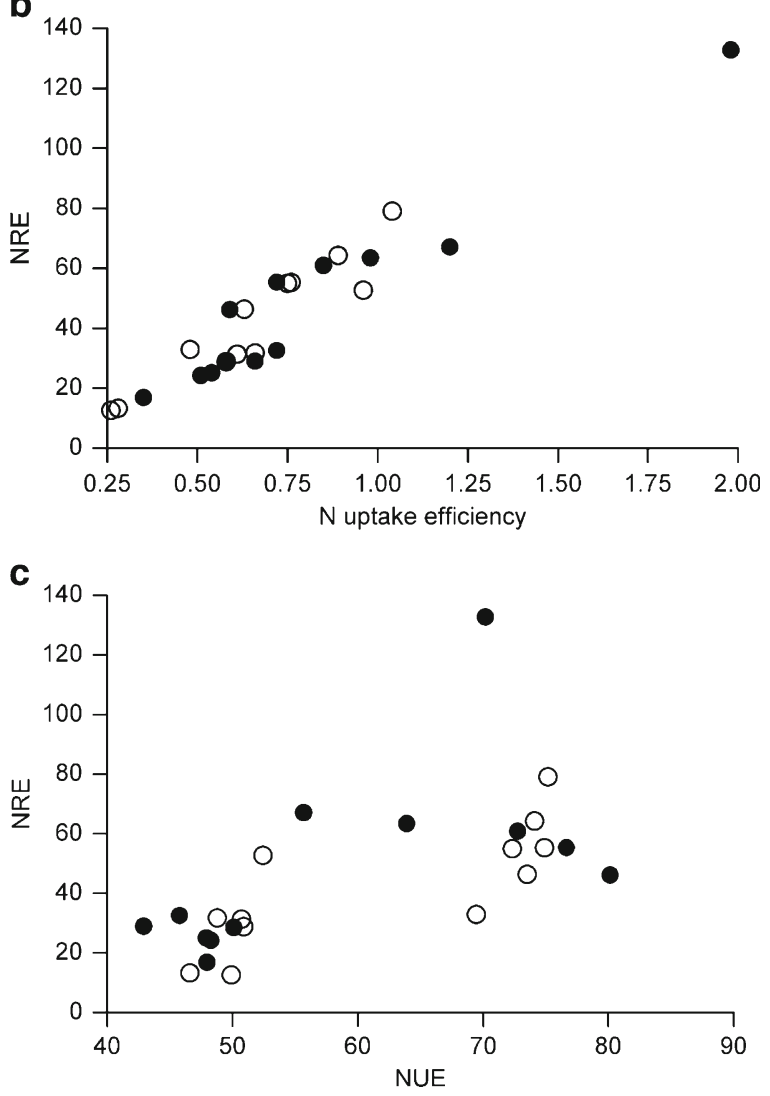

Fig. 1 Trends between $\mathrm{N}$ response efficiency (NRE) and (a) $\mathrm{N}$ supply, (b) $\mathrm{N}$ uptake efficiency and (c) $\mathrm{N}$ use efficiency (NUE) of a grassland in the Solling Mountains, Germany across different sward compositions, mowing frequency, and fertilization treatments. Each data point is the mean of six replicates per treatment ( $\bullet$ for 2009 , ○ for 2010). No statistical test was conducted because the $\mathrm{X}$ variables are components of the $\mathrm{Y}$ variable

thrice per year could also be caused by large $\mathrm{N}$ immobilization by the microbial community, which may result from increased rhizodeposition following defoliation (Holland et al. 1996). Such an explanation is corroborated by the findings of Guitian and Bardgett (2000) who observed increased soil microbial biomass caused by defoliation of grass.

Within the range of $\mathrm{N}$ supply covered in our study, the linear increase of plant $\mathrm{N}$ uptake was reflected by similar trends of increases in aboveground biomass yield and plant $\mathrm{N}$ concentrations (data not shown). The enhanced plant $\mathrm{N}$ uptake by more frequent mowing could be possibly due to 1) increased root-to-shoot ratio by intensive mowing (Kammann et al. 1998; Mooney and Winner 1991), which may then result in large nutrient uptake by plants, and 2) defoliation-induced increase in resource allocation to shoots, as reported by Guitian and Bardgett (2000) for grazing-tolerant grasses. However, for our study site, fine-root biomass and root length density measured in the control swards in September 2009 were not affected by mowing frequency (Rose et al. 2011). Thus, it is likely that our observed increased plant $\mathrm{N}$ uptake by more frequent mowing is due to increased resource allocation to shoots and overcompensatory response to defoliation (Ferraro and Oesterheld 2002; Guitian and Bardgett 2000).

Our finding that the dicot-enhanced swards (with equal proportions of dicots and monocots) did not result in a larger biomass yield compared to control and monocot-enhanced swards contrasts to the findings of Hector et al. (1999) and Weigelt et al. (2009) who reported a reduction of aboveground biomass with loss of functional groups in European grasslands. Furthermore, the number of plant species was not responsible for differences in biomass yield. Dicot-enhanced and monocot-enhanced swards showed no significant differences in biomass yield although the numbers of species were different, which is not consistent to the biodiversityproductivity theory (e.g. Hector et al. 1999; Tilman et al. 1996; Weigelt et al. 2009). However, as we only considered harvestable, aboveground biomass, inclusion of belowground biomass may lead to different results.

$\mathrm{N}$ response efficiency

To our knowledge, published information about NRE in grassland ecosystems is extremely limited and definitions of NRE are not consistent in literature (Xu et al. 2012; Aerts 1990; Vitousek 1982). Unlike other NRE and NUE studies that used litterfall N concentrations as an index of $\mathrm{N}$ availability (Vitousek 1982) or measured mineral $\mathrm{N}$ concentrations in soil 
Table $5 \mathrm{~N}$ uptake efficiency of a grassland under different management practices in the Solling Mountains, Germany

\begin{tabular}{|c|c|c|c|c|c|c|c|c|c|c|}
\hline \multicolumn{3}{|l|}{ Year } & \multicolumn{4}{|l|}{2009} & \multicolumn{4}{|l|}{2010} \\
\hline Main factors & Treatments & $n$ & $\begin{array}{l}\mathrm{N} \text { uptake efficiency } \\
(\mathrm{kg} \text { plant } \mathrm{N} \text { uptake } \\
\mathrm{kg} \mathrm{N} \text { supply }^{-1} \text { ) }\end{array}$ & SE & $P$ & $\begin{array}{l}\text { Variance } \\
\text { explained } \\
(\%)\end{array}$ & $\begin{array}{l}\mathrm{N} \text { uptake efficiency } \\
(\mathrm{kg} \text { plant } \mathrm{N} \text { uptake } \\
\mathrm{kg} \mathrm{N} \text { supply }^{-1} \text { ) }\end{array}$ & SE & $P$ & $\begin{array}{l}\text { Variance } \\
\text { explained } \\
(\%)\end{array}$ \\
\hline \multirow[t]{4}{*}{ Sward composition } & & & & & 0.372 & 2.13 & & & 0.056 & 6.04 \\
\hline & control & 24 & $0.65 \mathrm{a}$ & 0.08 & & & $0.80 \mathrm{a}$ & 0.11 & & \\
\hline & monocot-enhanced & 24 & $0.97 \mathrm{a}$ & 0.29 & & & $0.65 \mathrm{a}$ & 0.10 & & \\
\hline & dicot-enhanced & 24 & $0.80 \mathrm{a}$ & 0.10 & & & $0.52 \mathrm{a}$ & 0.06 & & \\
\hline \multirow[t]{3}{*}{ Mowing frequency } & & & & & 0.003 & 9.91 & & & $<0.001$ & 14.97 \\
\hline & once per year & 36 & $0.60 \mathrm{~b}$ & 0.05 & & & $0.56 \mathrm{~b}$ & 0.09 & & \\
\hline & thrice per year & 36 & $1.01 \mathrm{a}$ & 0.20 & & & $0.75 \mathrm{a}$ & 0.06 & & \\
\hline \multirow[t]{3}{*}{ Fertilization } & & & & & $<0.001$ & 16.79 & & & 0.006 & 7.90 \\
\hline & no & 36 & $1.05 \mathrm{a}$ & 0.20 & & & $0.76 \mathrm{a}$ & 0.07 & & \\
\hline & NPK & 36 & $0.56 \mathrm{~b}$ & 0.05 & & & $0.56 \mathrm{~b}$ & 0.08 & & \\
\hline
\end{tabular}

Mean values with different letter indicate significant differences among treatments within main factors or within an interaction of main factors (three-way ANOVA at $P \leq 0.05$ ). Treatment interactions that were not significant are not reported.

(Bridgham et al. 1995), we used in-situ measured net $\mathrm{N}$ mineralization rates as an index of soil plantavailable N (Hart et al. 1994). Our measured NRE values were smaller than those reported by Yuan et al. (2006) for a semi-arid grassland in China. Apart from site-specific differences between our and their study sites, the differences in NRE could also be due to the different measures used for $\mathrm{N}$ supply and biomass production. On the one hand, our estimate of $\mathrm{N}$ supply included fertilization, $\mathrm{N}$ deposition and cumulative net $\mathrm{N}$ mineralization rates during the growing season, resulting in large values of $\mathrm{N}$ supply and thus small NRE. On the other hand, Yuan et al. (2006) included not only aboveground but also belowground biomass production, which would lead to large NRE.

Our finding that NRE was largely influenced by fertilization was similar with those of Hiremath and Ewel (2001) who reported that NRE (which they termed ecosystem-level NUE) was negatively correlated with mean annual net nitrification rate, used as an index of soil $\mathrm{N}$ supply. The smaller NRE of the fertilized than unfertilized plots was caused by decreases in both $\mathrm{N}$ uptake efficiency and NUE. The monotonic increase in NRE with decreasing $\mathrm{N}$ supply was also consistent with the findings of Yuan et al. (2006), and was unlike the unimodal curve between NRE and soil net $\mathrm{N}$ mineralization rates (ranging from $25 \mathrm{~kg} \mathrm{~N} \mathrm{ha}^{-1} \mathrm{yr}^{-1}$ to $85 \mathrm{~kg} \mathrm{~N}$ $\mathrm{ha}^{-1} \mathrm{yr}^{-1}$ ) modelled by Bridgham et al. (1995) for temperate forests. This also supports the suggestion that the unimodal NRE curve may only be applicable for ecosystems with small $\mathrm{N}$ availability (Yuan et al. 2006). The second most important factor influencing NRE was mowing frequency. The increased NRE in plots cut thrice per year was largely due to increasing $\mathrm{N}$ uptake efficiency since NUE was either showing the opposite trend or not affected by mowing at all. The increased $\mathrm{N}$ uptake efficiency in plots cut thrice per year was caused by increased biomass yield and $\mathrm{N}$ concentration in biomass.

Finally, sward composition influenced NRE although to a lesser extent than fertilization and mowing frequency. Compared to the influence of sward compositions on biomass yield, where dicot-enhanced swards did not differ from control swards, the influence of sward composition on NRE was more pronounced and explained a larger part of the variance. The trends of NRE and N uptake efficiency among sward compositions were similar whereas NUE exhibited either opposite patterns or was not affected by sward composition. This emphasizes that NRE of the different sward compositions was influenced more by $\mathrm{N}$ uptake efficiency rather than by NUE and is contrary to the findings of van Ruijven and Berendse (2005) who observed an increasing NUE with increasing species richness in a grassland system without legumes. In our study site, legumes were only present in the control- (1-4\% abundance) and dicot-enhanced (4$9 \%$ ) swards. The presence of legumes however cannot support the pattern of differences in NRE among sward compositions but instead the interaction between sward composition and mowing frequency. For example, since we did not account the $\mathrm{N}$ input from $\mathrm{N}$-fixing legumes in 
Table $6 \mathrm{~N}$ use efficiency (NUE) of a grassland under different management practices in the Solling Mountains, Germany

\begin{tabular}{|c|c|c|c|c|c|c|c|c|c|c|}
\hline \multicolumn{3}{|l|}{ Year } & \multicolumn{4}{|l|}{2009} & \multicolumn{4}{|l|}{2010} \\
\hline Main factors & Treatments & $n$ & $\begin{array}{l}\text { NUE } \\
(\mathrm{kg} \text { biomass yield } \\
\mathrm{kg} \text { plant } \mathrm{N} \text { uptake }^{-1} \text { ) }\end{array}$ & SE & $P$ & $\begin{array}{l}\text { Variance } \\
\text { explained } \\
(\%)\end{array}$ & $\begin{array}{l}\text { NUE } \\
\text { (kg biomass yield } \\
\mathrm{kg} \mathrm{N} \text { supply }^{-1} \text { ) }\end{array}$ & SE & $P$ & $\begin{array}{l}\text { Variance } \\
\text { explained } \\
(\%)\end{array}$ \\
\hline \multirow[t]{4}{*}{ Sward composition } & & & & & 0.005 & 3.70 & & & 0.179 & 0.71 \\
\hline & control & 24 & $59.10 \mathrm{ab}$ & 2.71 & & & $63.07 \mathrm{a}$ & 2.70 & & \\
\hline & monocot-enhanced & 24 & $61.55 \mathrm{a}$ & 3.39 & & & $61.01 \mathrm{a}$ & 2.91 & & \\
\hline & dicot-enhanced & 24 & $54.90 \mathrm{~b}$ & 2.59 & & & $60.60 \mathrm{a}$ & 2.33 & & \\
\hline \multirow[t]{3}{*}{ Mowing frequency } & & & & & $<0.001$ & 8.38 & & & 0.455 & 0.11 \\
\hline & once per year & 36 & $62.65 \mathrm{a}$ & 2.67 & & & $61.12 \mathrm{a}$ & 2.15 & & \\
\hline & thrice per year & 36 & $54.39 \mathrm{~b}$ & 1.88 & & & $62.00 \mathrm{a}$ & 2.18 & & \\
\hline \multirow[t]{3}{*}{ Fertilization } & & & & & $<0.001$ & 63.42 & & & $<0.001$ & 83.06 \\
\hline & no & 36 & $69.88 \mathrm{a}$ & 1.91 & & & $73.23 \mathrm{a}$ & 1.04 & & \\
\hline & NPK & 36 & $47.16 \mathrm{~b}$ & 0.78 & & & $49.88 \mathrm{~b}$ & 0.71 & & \\
\hline $\begin{array}{l}\text { Fertilization } \mathrm{x} \\
\text { Mowing frequency }\end{array}$ & & & & & 0.003 & 3.07 & & & n.s. & \\
\hline no & once per year & 18 & $76.51 \mathrm{a}$ & 2.41 & & & & & & \\
\hline NPK & once per year & 18 & $48.78 \mathrm{c}$ & 0.99 & & & & & & \\
\hline no & thrice per year & 18 & $63.25 \mathrm{~b}$ & 2.01 & & & & & & \\
\hline NPK & thrice per year & 18 & $45.53 \mathrm{c}$ & 1.10 & & & & & & \\
\hline
\end{tabular}

Mean values with different letter indicate significant differences among treatments within main factors or within an interaction of main factors (three-way ANOVA with Tukey HSD at $P \leq 0.05$ ). Treatment interactions that were not significant are not reported. n.s. $=$ not significant.

our NRE calculation, this could have led to an underestimation of $\mathrm{N}$ supply and thus an overestimation of NRE in the control and dicot-enhanced swards. Instead we found that the monocot-enhanced swards (no legumes) had comparable NRE with the control and dicotenhanced swards all cut thrice a year and the lowest NRE was found in both monocot- and dicot-enhanced swards cut once per year (Table 4). The patterns of NRE cannot also be explained by the difference in plant species number. NRE of monocot-enhanced swards which had the smallest number (12-13) of species did not significantly differ from NRE of dicot-enhanced swards (17 species). According to Roy (2001) $90 \%$ of the biodiversity effect on productivity is reached at five species, implying that the difference in plant species in our experiment is larger than the threshold number and effects might not be detectable (Wrage et al. 2011). In contrast to the number of species, the proportions of plant functional groups did have a significant impact on NRE. The proportions of $\sim 30 \%$ dicots and $\sim 70 \%$ monocots found in the control swards showed the largest NRE. We think that over the past decades $\mathrm{N}$-limited conditions and prevailing management practices have led to an equilibrium in this grassland ecosystem in which optimal proportions of monocots and dicots developed to maximize NRE. As a result, an artificial increase in the proportion of dicots as well as in the proportion of monocots would lead to a smaller NRE. Thus, our results suggest that in addition to the effect of life-form diversity (Hiremath and Ewel 2001) also the proportions of different plant functional groups affect NRE of an ecosystem.

\section{Conclusions}

Our results show that management largely influenced NRE whereas plant functional group diversity only played a minor role. Fertilization decreased NRE due to decreases in both $\mathrm{N}$ uptake efficiency and NUE whereas mowing frequency and sward composition affected NRE through $\mathrm{N}$ uptake efficiency rather than NUE. The proportions of monocots and dicots in the control plots that were the result of long-term management practices had the largest NRE. Deviations from these proportions - even to more balanced proportions of monocots and dicots - decreased NRE. Our results show that NRE gives important insights in how different management can be evaluated to come up with a more 
sustainable grassland management. However, our study can only be a first step towards definite recommendations and NRE should be combined with an economic analysis before advices to farmers can be made.

Acknowledgments This work is part of the Cluster of Excellence 'Functional Biodiversity Research' and is funded by the State of Lower Saxony, the Ministry of Science and Culture and the Niedersächsisches Vorab. M.D. Corre acknowledges her funding from the Robert Bosch Foundation. We thank D. Boettger, N.C. Meyer, C. Gottwald and P. Aurin for support with experimental set up and field measurements. We thank I. Ostermeyer for the soil texture analysis and the technical assistants of the Soil Science laboratory and the Department of Plant Ecology for soil analyses. We thank T. From and U. Petersen from the Institute of Grassland Science for providing ground plant material and data on biomass yields. We thank C. Scherber for his support with the statistics and N. Wrage for reviewing this manuscript.

Open Access This article is distributed under the terms of the Creative Commons Attribution License which permits any use, distribution, and reproduction in any medium, provided the original author(s) and the source are credited.

\section{Appendix 1}

Table 7 Biomass yield of a grassland under different management practices in the Solling Mountains, Germany

\begin{tabular}{|c|c|c|c|c|c|c|c|c|c|c|}
\hline \multirow[t]{2}{*}{ Main factors } & \multirow[t]{2}{*}{ Treatments } & \multirow[t]{2}{*}{$n$} & \multicolumn{4}{|l|}{2009} & \multicolumn{4}{|l|}{2010} \\
\hline & & & $\begin{array}{l}\text { Biomass yield } \\
{ }^{\mathrm{a}}\left(\mathrm{kg} \mathrm{ha}^{-1} \mathrm{yr}^{-1}\right)\end{array}$ & SE & $P$ & $\begin{array}{l}\text { Variance } \\
\text { explained } \\
(\%)\end{array}$ & $\begin{array}{l}\text { Biomass yield } \\
{ }^{\mathrm{a}}\left(\mathrm{kg} \mathrm{ha}^{-1} \mathrm{yr}^{-1}\right)\end{array}$ & $\mathrm{SE}$ & $P$ & $\begin{array}{l}\text { Variance } \\
\text { explained } \\
(\%)\end{array}$ \\
\hline \multirow[t]{4}{*}{ Sward composition } & & & & & 0.648 & 0.28 & & & 0.007 & 2.34 \\
\hline & control & 24 & $7922.82 \mathrm{a}$ & 597.58 & & & $6132.01 \mathrm{a}$ & 536.79 & & \\
\hline & monocot-enhanced & 24 & $7763.22 \mathrm{a}$ & 508.89 & & & $5237.22 \mathrm{~b}$ & 498.97 & & \\
\hline & dicot-enhanced & 24 & $7586.48 \mathrm{a}$ & 482.80 & & & $5467.27 \mathrm{ab}$ & 467.66 & & \\
\hline \multirow[t]{3}{*}{ Mowing frequency } & & & & & $<0.001$ & 12.01 & & & $<0.001$ & 34.92 \\
\hline & once per year & 36 & $6855.40 \mathrm{~b}$ & 270.55 & & & $4146.09 \mathrm{~b}$ & 172.92 & & \\
\hline & thrice per year & 36 & $8659.62 \mathrm{a}$ & 517.05 & & & $7078.25 \mathrm{a}$ & 446.14 & & \\
\hline \multirow[t]{3}{*}{ Fertilization } & & & & & $<0.001$ & 56.74 & & & $<0.001$ & 24.71 \\
\hline & no & 36 & $5797.13 \mathrm{~b}$ & 167.30 & & & $4378.75 \mathrm{~b}$ & 210.25 & & \\
\hline & NPK & 36 & $9717.88 \mathrm{a}$ & 373.43 & & & $6845.59 \mathrm{a}$ & 469.71 & & \\
\hline $\begin{array}{l}\text { Mowing frequency } \\
\mathrm{x} \text { fertilization }\end{array}$ & & & & & $<0.001$ & 9.89 & & & $<0.001$ & 16.97 \\
\hline once per year & no & 18 & $5713.66 \mathrm{c}$ & 160.04 & & & $3934.60 \mathrm{~b}$ & 248.95 & & \\
\hline once per year & NPK & 18 & $7997.14 \mathrm{~b}$ & 349.87 & & & $4357.58 \mathrm{~b}$ & 236.35 & & \\
\hline thrice per year & no & 18 & $5880.61 \mathrm{c}$ & 297.99 & & & $4822.89 \mathrm{~b}$ & 311.13 & & \\
\hline thrice per year & NPK & 18 & 11438.62 a & 321.60 & & & $9333.61 \mathrm{a}$ & 352.58 & & \\
\hline
\end{tabular}

${ }^{\text {a }}$ Biomass yield data was reported by From et al. (2011).

Mean values with different letter indicate significant differences among treatments within main factors or within an interaction of main factors (three-way ANOVA with Tukey HSD at $P \leq 0.05$ ). Treatment interactions that were not significant are not reported.

\section{References}

Aerts R (1990) Nutrient use efficiency in evergreen and deciduous species from heathlands. Oecologia 84:391-397

Blake GR, Hartge KH (1986) Bulk density. In: Klute A (ed) Methods of soil analysis, part 1 . Physical and mineralogical methods. Soil Science Society of America, Madison, Wisconsin, USA, p 12

Bridgham SD, Pastor J, Mc Claugherty CA, Richardson CJ (1995) Nutrient-use efficiency - a litterfall index, a model, and a test along a nutrient-availability gradient in North-Carolina peatlands. Am Nat 145: $1-21$ 
Crawley MJ (2007) The R book. John Wiley \& Sons Ltd, Chinchester, West Sussex

Dawson LA, Grayston SJ, Paterson E (2000) Effects of grazing on the roots and rhizosphere of grasses. In: Lemaire $\mathrm{G}$, Hodgson J, de Moraes A, Nabinger C, De F. Carvalho PC (eds) Grassland ecophysiology and grazing ecology. CABI Publishing, Wallingfort, pp 61-84

Dobermann A (2005) Nitrogen use efficiency - state of the art. In IFA International Workshop on Enhanced-Efficiency Fertilizers, Frankfurt, Germany.

Ellenberg H, Leuschner C (2010) Vegetation Mitteleuropas mit den Alpen. Verlag Eugen Ulmer, Stuttgart

Ferraro DO, Oesterheld M (2002) Effect of defoliation on grass growth. A quantitative review. Oikos 98:125-133

Flombaum P, Sala OE (2008) Higher effect of plant species diversity on productivity in natural than artificial ecosystems. Proc Natl Acad Sci USA 105:6087-6090

From T, Petersen UK, Isselstein J (2011) Productivity and forage quality of a phytodiverse semi-natural grassland under various management regimes. doi:10.1038/ npre.2011.6622.1.

Guitian R, Bardgett RD (2000) Plant and soil microbial responses to defoliation in temperate semi-natural grassland. Plant Soil 220:271-277

Hart SC, Stark JM, Davidson EA, Firestone MK (1994) Nitrogen mineralization, immobilization, and nitrification. In: Weaver RW, Angle S, Bottomley P, Bezdicek D, Smith S, Tabatabai A, Wollum A (eds) Methods of soil analysis, Part 2. Microbiological and biochemical properties. Soil Science Society of America Book Series, Madison, Wisconsin, USA, pp 985-1018

Hassink J (1994) Effects of soil texture and grassland management on soil organic $\mathrm{C}$ and $\mathrm{N}$ and rates of $\mathrm{C}$ and $\mathrm{N}$ mineralization. Soil Biol Biochem 26:1221-1231

Hector A, Schmid B, Beierkuhnlein C, Caldeira MC, Diemer M, Dimitrakopoulos PG, Finn JA, Freitas H, Giller PS, Good J, Harris R, Hogberg P, Huss-Danell K, Joshi J, Jumpponen A, Korner C, Leadley PW, Loreau M, Minns A, Mulder CPH, O’Donovan G, Otway SJ, Pereira JS, Prinz A, Read DJ, Scherer-Lorenzen M, Schulze ED, Siamantziouras ASD, Spehn EM, Terry AC, Troumbis AY, Woodward FI, Yachi S, Lawton JH (1999) Plant diversity and productivity experiments in European grasslands. Science 286:1123-1127

Hiremath AJ, Ewel JJ (2001) Ecosystem nutrient use efficiency, productivity, and nutrient accrual in model tropical communities. Ecosystems 4:669-682

Holland EA, Detling JK (1990) Plant-response to Herbivory and belowground nitrogen cycling. Ecology 71:1040-1049

Holland JN, Cheng WX, Crossley DA (1996) Herbivore-induced changes in plant carbon allocation: assessment of belowground C fluxes using carbon-14. Oecologia 107:87-94

Holt JA (1997) Grazing pressure and soil carbon, microbial biomass and enzyme activities in semi-arid northeastern Australia. Appl Soil Ecol 5:143-149

Isselstein J, Jeangros B, Pavlu V (2005) Agronomic aspects of extensive grassland farming and biodiversity management. In: Lillak R, Viiralt R, Linke A, Geherman V (eds) Integrating efficient grassland farming and biodiversity; 13th international occasional symposium of the European Grassland Federation. Tartu, Estonia, pp 427-430
Iversen CM, Bridgham SD, Kellogg LE (2010) Scaling plant nitrogen use and uptake efficiencies in response to nutrient addition in peatlands. Ecology 91:693-707

Kammann C, Grunhage L, Muller C, Jacobi S, Jager HJ (1998) Seasonal variability and mitigation options for N2O emissions from differently managed grasslands. Environ Pollut 102:179-186

Keuffel-Türk A, Jankowski A, Scheler B, Rademacher P, Meesenburg $\mathrm{H}$ (in press) Stoffeinträge durch Deposition. In: Höper H, Landesamt für Bergbau MH (eds) Tagungsband 20 Jahre Boden-Dauerbeobachtung in Niedersachsen. Energie und Geologie, Hannover

König N, Fortmann H (1996) Probenvorbereitungs-, Untersuchungs- und Elementbestimmungs- Methoden des Umweltanalytik-Labor der Niedersächsischen Forstlichen Versuchsanstalt und des Zentrallabor II des Forschungszentrums Waldökosysteme. Teil 1: Elementbestimmungsmethoden A-M. Berichte des Forschungszentrums Waldökosysteme der Universität Göttingen.

Kuzyakov Y, Friedel JK, Stahr K (2000) Review of mechanisms and quantification of priming effects. Soil Biol Biochem 32:1485-1498

Mikola J, Yeates GW, Barker GM, Wardle DA, Bonner KI (2001) Effects of defoliation intensity on soil food-web properties in an experimental grassland community. Oikos 92:333-343

Mikola J, Setala H, Virkajarvi P, Saarijarvi K, Ilmarinen K, Voigt W, Vestberg M (2009) Defoliation and patchy nutrient return drive grazing effects on plant and soil properties in a dairy cow pasture. Ecol Monogr 79:221-244

Mooney HA, Winner WE (1991) Partitioning response of plants to stress. In: Mooney HA, Winner WE, Pell EJ (eds) Responses of plants to multiple stresses. Academic Press, San Diego, pp 129-141

Northup BK, Brown JR, Holt JA (1999) Grazing impacts on the spatial distribution of soil microbial biomass around tussock grasses in a tropical grassland. Appl Soil Ecol 13:259-270

Pastor J, Bridgham SD (1999) Nutrient efficiency along nutrient availability gradients. Oecologia 118:50-58

Petersen U, Wrage N, Köhler L, Leuschner C, Isselstein J (2011) Manipulating the species composition of permanent grasslands - a new approach to biodiversity experiments. Basic Appl Ecol. doi:10.1016/j.baae.2011.10.003

Pykälä J (2000) Mitigating human effects on European biodiversity through traditional animal husbandry. Conserv Biol 14:705-712

R Development Core Team (2009) R: A language and environment for statistical computing. R Foundation for Statistical Computing, Vienna, Austria

Rose L, Coners H, Leuschner C (2011) Effects of fertilization and cutting frequency on the water balance of a temperate grassland. Ecohydrology.

Roy J (2001) How does biodiversity control primary productivity? In: Roy J, Saugier B, Mooney HA (eds) Terrestrial global productivity. Academic Press, San Diego

Sankaran M, Augustine DJ (2004) Large herbivores suppress decomposer abundance in a semiarid grazing ecosystem. Ecology 85:1052-1061

Schlichting E, Blume HP, Stahr K (1995) Bodenkundliches Praktikum. Blackwell Wissenschafts-Verlag, Berlin, Wien, 295

Tilman D, Wedin D, Knops J (1996) Productivity and sustainability influenced by biodiversity in grassland ecosystems. Nature 379:718-720 
Van Ruijven J, Berendse F (2005) Diversity-productivity relationships: Initial effects, long-term patterns, and underlying mechanisms. Proc Natl Acad Sci USA 102:695-700

Vitousek P (1982) Nutrient cycling and nutrient use efficiency. Am Nat 119:553-572

Vitousek PM, Howarth RW (1991) Nitrogen limitation on land and in the sea - how can it occur. Biogeochemistry 13:87-115

Weigelt A, Weisser WW, Buchmann N, Scherer-Lorenzen M (2009) Biodiversity for multifunctional grasslands: equal productivity in high-diversity low-input and low-diversity high-input systems. Biogeosciences 6:1695-1706
Wrage N, Strodthoff J, Cuchillo MH, Isselstein J, Kayser M (2011) Phytodiversity of temperate permanent grasslands: Ecosystem services for agriculture and livestock management for diversity conservation. Biodivers Conserv. doi:10.1007/s10531-011-0145-6, 3317-3339

Xu G, Fan X, Miller AJ (2012) Plant nitrogen assimilation and use efficiency. Annu Rev Plant Biol 63:153-182

Yuan ZY, Li LH, Han XG, Chen SP, Wang ZW, Chen QS, Bai WM (2006) Nitrogen response efficiency increased monotonically with decreasing soil resource availability: a case study from a semiarid grassland in northern China. Oecologia 148:564-572 